\title{
The 1956 Qingdao Meeting on Genetics: an important turning point of Chinese biology
}

\author{
Ming Li, Le Kang \\ Beijing Institutes of Life Science, Chinese Academy of Sciences, Beijing 100101, China
}

Lysenkoism once was a popular word in the middle of the last century, but is now long forgotten by most people. Many young Chinese have never heard of T. D. Lysenko or Lysenkoism, neither do they know the impact Lysenkoism had on the history of biology in the former Soviet Union, in Eastern Europe, and in China.

To put a long story short, Trofim Denisovich Lysenko was a Soviet agronomist who believed in inheritance of environmentally acquired traits. Starting in the 1930s, he received political support from the Soviet leaders and was gradually promoted to the top leader of the Academy of Agricultural Sciences of the Soviet Union. With the political influence and power in his hand, Lysenko began to promote his theory throughout the nation and eliminate any "harmful" ideas (i.e. Mendelian genetics) among Soviet biologists. The following events were more of a political movement than a scientific discussion, as Mendelian genetics was officially banned in the Soviet Union in 1948 and over 3000 scientists were expulsed from their positions. Many Soviet scientists were thrown into prison for expressing opinions dissent from Lysenko's, and quite a lot suffered persecution severely, including the internationally renowned biologist Nikolai Vavilov.

The Lysenkoism started to affect Chinese biology after the founding of the People's Republic of China in 1949. As a wartorn nation, the new China had to re-build literally everything from scratch, especially industry and science \& technology. "Learning from the Soviet Union" was a major policy for Chinese industry and S\&T, and the Soviet Union was generous to help. Thousands of Soviet experts and consultants were sent to China, bringing with them knowledge and technologies that were mainstream in the Soviet Union, including Lysenko's theories. Hundreds of Soviet scientists in biology, most of whom were Lysenko's followers, gave introductory courses in Chinese universities and institutes, and their lectures were translated into Chinese textbooks and widely spread in China. For a while, one may find both
Lysenko's theories and Mendelian genetics in the same biology textbooks in China.

However, the co-existence of Lysenkoist biology and Mendelian genetics in Chinese biology curriculums did not last long. As most senior Chinese biologists were westerntrained returnees and some of them even had worked in the Morgan laboratory, it was understandable that they could not completely agree with Lysenko's theories and some openly expressed their opinions about it. Unfortunately the influence of Lysenkoism in China was not only scientific but also political. In 1952, the government media sharply criticized the Mendelian genetics and its supporters, and the Mendelian genetics was forcedly taken out of all Chinese biology textbooks afterwards. Most biologists managed to cope with the circumstances-they taught the newly-edited textbooks and kept their different opinions to themselves, and quietly continued their genetic research. But some were not that lucky, including plant geneticist Wenkui Bao. His research of rice polyploid had been making steady progress and was reaching a critical point when the authorities ordered him to stop his work and destroyed all of his experimental plots. Unlike the Soviet Union, Lysenkoism did not develop into a severe political movement in general in China.

In 1956, the political atmosphere in the Soviet Union was going through abrupt changes and Lysenko was dismissed from his position as the leader of the Academy of Agricultural Sciences of the Soviet Union. Meanwhile, Chinese leaders were re-evaluating China's S\&T power and started to consider whether the full dependency on Soviet expertise was necessary for the S\&T development. The government decided to start a campaign called "Hundred Flowers Blossom, and Hundred Schools Contend," encouraging a variety of views on national policy issues, including S\&T issues. Seizing the moment, leaders of Chinese Academy of Sciences and the Ministry of Education wrote to the higher authorities and asked them to reconsider the issue of genetics, which eventually led to the Qingdao Meeting on 
Genetics on August 10-25, 1956. Qingdao, a beautiful city in the east coast of China, became more well-known due to the important meeting.

The 16-day long meeting invited 54 Chinese biologists, including not only geneticists (both Lysenko's followers and Mendelian geneticists), but also biologists from all other disciplines (embryo biologists, biochemists, cell biologists, ecologists, and so on). Over 70 representatives from various governmental departments also attended the meeting, but they were only to observe. At the opening ceremony, Chair Dizhou Tong, a leader and biologist of the Academic Division of Biology in the Chinese Academy of Sciences, delivered an opening speech about the goals and the ground rules of the meeting and asked all the participating scientists to give over their inhibition and speak out freely and boldly. For the first time in seven years, scientists were able to discuss modern genetics without any political distortion. Almost all the discussions during the meeting were technical and they were organized into the following sessions: the material basis of inheritance, the relationship between genetic mutation and environment, inheritance and individual development, inheritance and phylogeny, education of genetics and S\&T policy. The Mendelian geneticists presented detailed experimental data from each field of biology related to genetics, as well as the latest reports on genetics from western countries. Most often, their Lysenkoist antagonists had to take a defensive posture or merely repeat their position on the main topic. Anyhow, the meeting was an open forum, not a debate, and the purpose was not to prove one theory was right and the other was wrong. At the end of the meeting, all the participating biologists reached an agreement for future academic freedom and mutual understanding.

Later on, the meeting materials were printed and widely distributed to educate a broader public. And most Chinese textbooks for secondary and higher education started to teach both Mendelian genetics and Lysenko's theories. Although it took some time later for Chinese genetics to go back to the right track, the 1956 Qingdao Meeting on Genetics was definitely a turning point along the twisted path of Chinese biology development. Not only did the meeting bring Chinese genetics to the right path, it also started a new era for the overall Chinese S\&T development. Since the meeting, a basic rule was set for Chinese S\&T policy-let the scientists (not the government) decide on important S\&T issues and never turn academic controversy into political movements. For this reason, the meeting should not be forgotten by the new-generation Chinese scientists while they enjoy the academic freedom in China.

\section{REFERENCES}

Peishan Li. (1985). History of Science and Technology in the $20^{\text {th }}$ Century. Beijing: Science Press. (李佩珊, 许良英. 《20世纪科学 技术简史》, 科学出版社, 北京. 1985.)

Peishan Li, et al.. (1985). Memorandum of Qingdao Meeting on Genetics, August, 1956 - The Only Correct Way for the Development of Science-Hundred Schools Contend. Beijing: The Commercial Press. (李佩珊, 等. 《百家争鸣—发展科学的必由之 路一-1956年8月青岛遗传学座谈会纪实》. 商务印书馆, 北京. 1985.) 